\author{
Adam Mazurkiewicz \\ ORCID: 0000-0003-3804-6445 \\ Uniwersytet Łódzki
}

\title{
Filmowy horror oczami młodych naukowców
}

DOI: $10.19195 / 0867-7441.24 .24$

Recenzja: Spotkania z gatunkami filmowymi. Horror, red. Bogumiła Fiołek-Lubczyńska, Agnieszka Barczyk, Renata Nolbrzak, Wydawnictwo Uniwersytetu Łódzkiego, Łódź 2014, ss. 138.

Słowa kluczowe: kino grozy, horror japoński, przemoc, „Nowa Historia Filmu”, „studium przypadku"

Keywords: horror cinema, Japan horror, violence, "New Film History”, "Case Studies"

Działające przy Wydziale Filologicznym Uniwersytetu Łódzkiego Koło Krytyków Filmowych UŁ tomem Spotkania z gatunkami filmowymi. Horror zainicjowało serię wydawniczą, która — w myśl redaktorów zbioru — intencjonalnie ma przybliżyć czytelnikowi osobliwości „kina gatunków” (określenie Roberta Altmana; notabene badacz ten z niezrozumiałych względów nie zostaje przywołany w tomie) ${ }^{1}$. Dotychczas nie ukazała się kontynuacja serii, jednakże miejmy nadzieję, że zmieni się to w najbliższych latach. Tym bardziej że omawiany tu zbiór stanowi pozycję szczególną. Jego współautorami są bowiem początkujący badacze, pośród których nie zabrakło słuchaczy studiów magisterskich i doktoranckich. Dla wielu z nich pomieszczone w tomie szkice stanowią zresztą juwenilia, pozostające tyleż świadectwem zainteresowań ich autorów, co (być może) zapowiadające kierunki rozwoju refleksji filmoznawczej² .

${ }^{1}$ Zob. B. Fiołek-Lubczyńska, A. Barczyk, R. Nolbrzak, Od Redakcji, [w:] Spotkania z gatunkami filmowymi. Horror, red. B. Fiołek-Lubczyńska, A. Barczyk, R. Nolbrzak, Łódź 2014, s. 8.

${ }^{2}$ Uwaga ta nie jest oczywiście jednoznaczna z rozliczaniem autorów z ich pomysłów interpretacyjnych przy zastosowaniu „taryfy ulgowej”. Skoro zdecydowali się na ich prezentację w pracy o charakterze naukowych studiów, to powinni się liczyć z merytoryczną dyskusją ze strony innych badaczy; jak ważne jest zachowanie przy tym kultury polemiki, świadczy zapis w Dobrych obyczajach w nauce. Zbiorze zasad $i$ wytycznych, akcentujący konieczność argumentacji z poszanowaniem 
Rozważane z zaproponowanej tu perspektywy szkice młodych (stażem i wiekiem) krytyków można byłoby odczytywać jako propozycję metodologiczną komplementarną wobec skodyfikowanych przez Thomasa Elsaessera założeń Nowej Historii Filmu ${ }^{3}$. Tym, co zwraca uwagę w Spotkaniach z gatunkami filmowymi. Horrorze, jest bowiem filologiczna perspektywa lektury przywoływanych obrazów. Film w tym ujęciu jest tekstem kultury rozważanym ze względu na relację między jego formą i treścią, wobec której to zależności wszelkie inne uwarunkowania ,zewnętrzne” zostają przywoływane na prawach kontekstu.

W dobie ekspansji zainteresowań pozatekstowymi aspektami produkcji filmowych takie „tradycyjne” podejście do sztuki filmowej pozornie nosi znamiona anachronizmu; znaczące pod tym względem w rodzimym namyśle badawczym pozostają prace między innymi Marcina Adamczaka i Łukasza Biskupskiego ${ }^{4}$. Trudno zarazem jednak oprzeć się wrażeniu, że — zważywszy na specyfikę „kina gatunków" - oraz tematyczne wybory współautorów Spotkań z gatunkami filmowymi perspektywa studiów produkcyjnych nie sprawdziłaby się w stopniu równie satysfakcjonującym poznawczo, jak podejście „tekstologiczne”. Zwłaszcza że w omawianym zbiorze przeważają „studia przypadków” (tak też zatytułowana została najobszerniejsza część tomu), w ramach których omówione zostały filmy adresowane do różnych grup miłośników kina grozy.

Pośród szkiców przeważają omówienia dokonań azjatyckiego filmu — zarówno w ujęciu jednostkowym (znaczący pod tym względem pozostaje szkic Szymona Cieślińskiego, poświęcony filmowi Piła Jamesa Wana), jak i syntetyzującym wybrane nurty i motywy (Mateusz Krzekotowski pisze o specyfice japońskiego stylu ero-guro-nansensu, a Katarzyna Kobos omawia zagadnienia moty-

zasad rzeczowości i rzetelności (zob. ibidem, § 5.5, http://www.paleo.pan.pl/documents/Kodeks Etyczny_PAN.pdf [dostęp: 11.08.2016]). Należy jednak mieć na względzie specyfikę naukowych „pierwszych wzlotów” i nie traktować początkujących autorów równie surowo jak badaczy o ustalonej pozycji w środowisku naukowym. Łatwo może dojść wówczas bowiem do nieporozumień i zaniżonej oceny. Innymi słowy — odwołując się do powiedzenia tytułowego protagonisty Pana Jowialskiego Aleksandra Fredry — należy „znać proporcję".

${ }^{3}$ Zob. T. Elsaesser, Nowa Historia Filmu jako archeologia mediów, przeł. G. Nadgrodkiewicz, „Kwartalnik Filmowy” 2009, nr 67-68, s. 8-41. Syntetyzującym wprowadzeniem do założeń Nowej Historii Filmu pozostaje szkic Marka Henrykowskiego Metodologia Nowej Historii Filmu („Images” 2015, nr 26, s. 311-316). Do pewnego stopnia postulaty Elsaessera współbrzmią z założeniami production studies, o czym świadczy deklaracja zakresu zainteresowań Nowej Historii Kina: „Kolejne fazy kina, ale też relacje kina do innych form medialnych, takich jak telewizja, sztuka wideo i media cyfrowe, mogą być mapowane przez analizowanie ich rozmaitych i odrębnych światów diegetycznych, które obejmują zarówno aparat techniczny, jak i dyspozytywy umysłowe, ale które również są zależne od czasowych, przestrzennych i enuncjatywnych lokalizatorów oraz aktywatorów wspólnie konstytuujących specyficzne »ontologie« tych światów” (T. Elsaesser, op. cit., s. 29).

${ }^{4}$ Zob. np. M. Adamczak, Globalne Hollywood. Filmowa Europa i polskie kino po 1989 roku, Gdańsk 2010; idem, Obok ekranu. Perspektywa badań produkcyjnych a społeczne istnienie filmu, Poznań 2014; Ł. Biskupski, Miasto Atrakcji. Narodziny kultury masowej na przetomie XIX i XX wieku. Kino w systemie rozrywkowym Łodzi, Warszawa 2013. 
wiczne azjatyckiego kina grozy z perspektywy topopoetyki). Do pewnego stopnia jako komplementarny wobec przywołanych tu szkiców należy uznać artykuł Katarzyny Żakiety, poświęcony tendencjom rozwojowym współczesnego (a zatem i azjatyckiego) kina grozy. Artykuł ten jest szczególnie interesujący ze względu na komparatystyczne ujęcie omawianego zagadnienia, pozwalającego sytuować ewolucję filmowych „opowieści z dreszczykiem” zarówno w kontekście globalizujących trendów, jak i filmografii narodowych. Napięcie między tymi obiema perspektywami umożliwiło autorce dostrzeżenie dynamiki rozwoju gatunku, odpowiadającego na „horyzont oczekiwań” (określenie Hansa Roberta Jaussa) widzów spragnionych przeżycia — niekiedy skrajnych — emocji, stymulowanych kinowymi obrazami.

Szkic Żakiety koresponduje zresztą nie tylko z artykułami poświęconymi kinu azjatyckiemu; należy czytać go bowiem przede wszystkim w kontekście rozważań Rafała Świeckiego nad początkami kina jako sztuki i pojawiającymi się już w pierwszych filmach akcentami charakterystycznymi dla fantastyki grozy (badacz zalicza do nich między innymi kinową adaptację Frankensteina w reżyserii Jamesa Searle'a Dawleya z 1910 roku oraz Studenta z Pragi Stellana Rye, 1913)5. Oba szkice — Żakiety i Świeckiego — mogą też być czytane jako dwugłos w dyskusji nad ewolucją światowego kina grozy (nieprzypadkowo oba artykuły zostały umieszczone w części zatytułowanej Kierunki rozwoju).

Odmienny charakter mają szkice pomieszczone w rozdziale opatrzonym enigmatycznym (i nie do końca trafnie dobranym) tytułem Zamiast wstępu. Niezbyt fortunne jest w tym wypadku nie tyle ukształtowanie stylistyczne tytułu (co bowiem zamiast wstępu?), ile mylące zakreślenie tematyki szkiców, które zostały umieszczone w tej partii. Są one nie tyle wprowadzeniem do nadrzędnej problematyki zbioru (to jest filmowego horroru), ile nakreślają konteksty interpretacyjne szkiców syntetyzujących omawiane zagadnienia bądź mających charakter ,studiów przypadków".

Zarazem część ta jest najmniej zwarta tematycznie, a jednocześnie porusza kwestie nieobecne zazwyczaj w funkcjonujących na rodzimym rynku wydawniczym opracowaniach dotyczących kinowej fantastyki grozy. Zarówno namysł nad rolą dźwięku w tworzeniu nastroju, jak i badania o charakterze empirycznym nad recepcją fantastyki grozy wśród młodego (zarówno wiekiem, jak i stażem) odbiorcy są bowiem marginesem zainteresowań ${ }^{6}$. Tym bardziej zatem szkoda, że

${ }^{5}$ Co ciekawe, i w tym szkicu pojawia się japoński akcent; autor, pisząc o początkach kina, przywołuje dwa tytuły: Bake Jizo (化け地蔵, 1896, reż. Shiro Asano) oraz Shinin no Sosei (しにんのそせい, 1898, reż. Shiro Asano); zob. R. Świecki, Powstanie i rozwój horroru — kino nieme i początki kina dźwiękowego, [w:] Spotkania z gatunkami..., s. 43.

${ }^{6}$ Jednym z niewielu w polskiej refleksji naukowej, merytorycznie ważkich studiów, poświęconych sposobowi istnienia muzyki w filmie grozy jest szkic Krzysztofa Kozłowskiego Muzyka i horror. „Lśnienie” Stanleya Kubricka („Images” 2009-2010, nr 13-14, s. 47-64). Do pewnego stopnia pouczające może być też syntetyczne opracowanie Pawła Łudzenia Konstrukcja muzyki do horroru („Klub Miłośników Filmu”, http://film.org.pl/soundtrack/muzyka_w_horrorze/wstep/ 
redaktorzy tomu nie zdecydowali się wyeksponować tej części w sposób zdecydowanie bardziej zachęcający do lektury.

Zważywszy na obserwowane od niejakiego czasu zainteresowanie kinem grozy, przejawiające się w sukcesywnie publikowanych opracowaniach ${ }^{7}$, należy zadać sobie pytanie o to, w jakiej mierze Spotkania z gatunkami filmowymi wprowadzają nową perspektywę do stanu badań nad filmowymi „opowieściami z dreszczykiem". Niezaprzeczalnie autorzy pomieszczonych w tomie szkiców omawiają zagadnienia dotychczas pomijane lub marginalizowane w rodzimej refleksji naukowej. Nawet wówczas gdy przywołują relatywnie dobrze rozpoznaną kinematografię Dalekiego Wschodu, nie czynią tego w sposób powielający dotychczasowe ustalenia przywołanych badaczy, między innymi Krzysztofa Gonerskiego i Dawida Głowni.

Trudno zarazem zgodzić się na zaproponowany przez redakcję edytorski kształt tomu: w kontekście liczby przytaczanych tytułów filmów i nazwisk należałoby oczekiwać dołączenia indeksu, umożliwiającego czytającym sprawne odszukiwanie wspominanych twórców i ich dzieł. Być może lepszym rozwiązaniem też niż umieszczanie bibliografii pod każdym artykułem byłoby zestawienie jej jako osobnej całości. Dzięki temu mogłaby być ona doskonałym punktem wyjścia do poszukiwań własnych odbiorcy. Już choćby z tego względu zamieszczenie owych zestawień jest bardziej konieczne niż informacje na temat biogramów badaczy współtworzących omawiany tom.

Niemniej, mimo wskazanych tu usterek, nie można uznać Spotkań z gatunkami filmowymi za pozycję chybioną. Owszem, autorom można zarzucić brak pogłębionego spojrzenia na omawiane zagadnienia, jednakże wnika ono raczej ze wspominanego nikłego stażu badawczego niż braku kompetencji. Miejmy zatem nadzieję, że kolejne, zapowiadane we wstępie spotkania z filmowymi gatunkami, nie tylko dojdą wreszcie do skutku, lecz także zaowocują równie interesującą, jak rozważania nad kinowym horrorem, publikacją.

wstep2.html [dostęp: 11.08.2016]), ma ono jednak charakter popularnonaukowy. Pewne uwagi na temat muzyki w horrorze pojawiają się też w pracy Macieja Żołnowskiego Fenomen grozy w muzyce (Gliwice 2006, s. 45-91), trudno jednak pozycję tę uznać za merytorycznie istotną; autor skupia się w niej głównie na streszczeniu wybranych filmów i wypunktowaniu zabiegów muzycznych współtworzących nastrój grozy. Dodatkowym utrudnieniem lekturowym jest afektowany styl i niefunkcjonalne przywoływanie obszernych cytatów.

${ }^{7}$ Należą do nich między innymi następujące pozycje, wydane w latach 2006-2013: B. Paszylk, Leksykon filmowego horroru, Michałów-Grabina 2006; P.K. Rodan, Polski horror czyli o filmie grozy stów kilka, Łódź 2008; K. Gonerski, Strach na skośne oczy. Azjatyckie kino grozy, Skarżysko-Kamienna 2010; G. Podsiadło, Film gore - komercjalizacja gatunku, Warszawa 2011; P. Sawicki, Odrażajace, brudne, złe. 100 filmów gore, Wrocław 2011; D. Głownia, Sześć widoków na kinematografie japońską. Kulturowe, społeczne, polityczne i instytucjonalne konteksty kina, Wrocław 2013. 


\section{Bibliografia}

\section{Opracowania}

Adamczak M., Globalne Hollywood. Filmowa Europa i polskie kino po 1989 roku, słowo/obraz terytoria, Gdańsk 2010.

Adamczak M., Obok ekranu. Perspektywa badań produkcyjnych a spoleczne istnienie filmu, Wydawnictwo UAM, Poznań 2014.

Biskupski Ł., Miasto Atrakcji. Narodziny kultury masowej na przełomie XIX i XX wieku. Kino w systemie rozrywkowym Łodzi, Narodowe Centrum Kultury, Warszawa 2013.

Elsaesser T., Nowa Historia Filmu jako archeologia mediów, przeł. G. Nadgrodkiewicz, „Kwartalnik Filmowy" 2009, nr 67-68.

Fiołek-Lubczyńska B., Barczyk A., Nolbrzak R., Od Redakcji, [w:] Spotkania z gatunkami filmowymi. Horror, Wydawnictwo Uniwersytetu Łódzkiego, Łódź 2014.

Głownia D., Sześć widoków na kinematografie japońska. Kulturowe, społeczne, polityczne i instytucjonalne konteksty kina, Wydawnictwo Yohei, Wrocław 2013.

Gonerski K., Strach na skośne oczy. Azjatyckie kino grozy, Wydawnictwo Kwiaty Orientu, Skarżysko-Kamienna 2010.

Henrykowski M., Metodologia Nowej Historii Filmu, „Images” 2015, nr 26.

Kozłowski K., Muzyka i horror. „Lśnienie” Stanleya Kubricka, „Images” 2009-2010, nr 13-14.

Paszylk B., Leksykon filmowego horroru, Instytut Wydawniczy Latarnik, Michałów-Grabina 2006.

Podsiadło G., Film gore - komercjalizacja gatunku, Drukarnia Cyfrowa Sowa, Warszawa 2011.

Rodan P.J., Polski horror czyli o filmie grozy słów kilka, Wydawnictwo Audiowizualne Nemezis, Łódź 2008.

Sawicki P., Odrażajace, brudne, złe. 100 filmów gore, Wydawnictwo Yohei, Wrocław 2011

Świecki R., Powstanie i rozwój horroru — kino nieme i początki kina dźwiękowego, [w:] Spotkania z gatunkami filmowymi. Horror, red. B. Fiołek-Lubczyńska, A. Barczyk, R. Nolbrzak, Wydawnictwo Uniwersytetu Łódzkiego, Łódź 2014.

Żołnowski M., Fenomen grozy w muzyce, Internetowe Wydawnictwo „Złote Myśli”, Gliwice 2006.

\section{Źródla internetowe}

Łudzeń P., Konstrukcja muzyki do horroru, „Klub Miłośników Filmu”, http://film.org.pl/soundtrack/muzyka_w_horrorze/wstep/wstep2.html.

\section{Filmografia}

Bake Jizo, reż. Shiro Asano, Japonia 1896.

Shinin no Sosei, reż. Shiro Asano, Japonia 1898. 